\title{
Archeological Investigations on the Weyerhaeuser Land Exchange Sites, McCurtain County, Oklahoma: An Update
}

Meeks Etchieson

Unknown

Follow this and additional works at: https://scholarworks.sfasu.edu/ita

Part of the American Material Culture Commons, Archaeological Anthropology Commons, Environmental Studies Commons, Other American Studies Commons, Other Arts and Humanities Commons, Other History of Art, Architecture, and Archaeology Commons, and the United States History Commons

Tell us how this article helped you.

This Article is brought to you for free and open access by the Center for Regional Heritage Research at SFA ScholarWorks. It has been accepted for inclusion in Index of Texas Archaeology: Open Access Gray Literature from the Lone Star State by an authorized editor of SFA ScholarWorks. For more information, please contact cdsscholarworks@sfasu.edu. 


\section{Archeological Investigations on the Weyerhaeuser Land Exchange Sites, McCurtain County, Oklahoma: An Update}

\section{Creative Commons License}

\section{(c) (1) (8)}

This work is licensed under a Creative Commons Attribution-NonCommercial 4.0 International License 


\title{
Archeological Investigations on the Weyerhaeuser Land Exchange Sites, McCurtain County, Oklahoma: An Update ${ }^{1}$
}

\author{
Meeks Etchieson \\ Heritage Program Manager, Ouachita National Forest
}

\begin{abstract}
This paper provides a brief overview of the testing work completed to date on sites within the Tiak Ranger District, Ouachita National Forest, McCurtain County, Oklahoma. This work was part of the requirements outlined in the Programmatic Agreement for the Ouachita National Forest/Weyerhaeuser Company Land Exchange. Nine prehistoric sites have been tested to determine their eligibility for inclusion on the National Register of Historic Places. Each site contains a Caddoan component. Six sites are believed to be eligible for listing.
\end{abstract}

\section{INTRODUCTION}

In 1996, the Ouachita National Forest and Weyerhaeuser Company completed a large land exchange affecting approximately 28,000 acres of national forest lands and approximately 150,000 acres of Weyerhaeuser lands in McCurtain County, Oklahoma. An additional 55,000 acres of project lands $(20,000$ acres of federal lands and 35,000 acres of Weyerhaeuser lands) are located in Arkansas. Archeological surveys on the affected federal lands had identified a total of 200 archeological sites, of which 58 were believed to be potentially eligible for inclusion on the National Register and which needed further evaluation (Etchieson 1997:18).

In an effort to outline needed archeological work and responsibilities, the Ouachita National Forest entered into negotiations, in October 1995, with Weyerhaeuser Company, the State Historic Preservation officers of Arkansas and Oklahoma, the Oklahoma Archeological Survey, the Caddo Tribe, the Choctaw Nation, and the Advisory Council on Historic Preservation (Etchieson 1997:19).

1 A shorter version of this paper was presented at the East Texas Archeological Meeting, Kilgore, Texas, 25 March 2000. 
This resulted in the development of a Programmatic Agreement signed by all the parties (Ouachita National Forest 1996). This agreement outlined the tasks necessary for the Ouachita National Forest to complete its Section 106 responsibilities under the National Historic Preservation Act.

The purpose of this paper is to provide an update on the work that the Ouachita National Forest has completed to date on potentially eligible sites in southeastern McCurtain County, Oklahoma. This paper should not be viewed as a presentation of the analysis of testing results nor should interpretations be considered as the final word. The laboratory processing and analysis of collections and data is ongoing. Archeological surveys were completed on a sample of the exchange lands, locating an additional 101 prehistoric and historic sites on the McCurtain County lands. Choctaw allotment records were examined and 35 historic farmsteads were identified and documented (Etchieson 1997:20-21). Perttula (1997) examined the ceramics recovered from the survey phase of these investigations and provided a brief report on this analysis.

\section{DISCUSSION OF TESTING PROGRAM}

Beginning in November 1996, evaluation testing began on those sites that were believed to be potentially eligible for inclusion on the National Register. The status of the evaluation on the first two sites examined was reported in 1997 at the Caddo Conference held in Norman and Anadarko, Oklahoma, and at the Oklahoma Anthropological Society meeting, also in Norman, Oklahoma (Etchieson 1997). Both sites, 34MC737 and 34MC254, contain Caddoan components; the results of the investigations at these two sites are only briefly summarized here.

During the initial site identification and documentation process, a series of shovel tests were excavated on a $5-10$ meter grid across the landforms to determine extent of the sites, depth of deposits and concentrations of materials/features.
Formal excavation units on each site are based on the results of that shovel test grid; units are placed in those areas where it is believed that the greatest potential for intact deposits and features exist.

\section{$34 M C 737$}

This site contains a low-medium density lithic and ceramic scatter within a series of low sandy clay knolls on the floodplain of Surratt Creek. A total of 36 sherds were recovered from the testing; these are largely grog or grog/grit tempered. Decoration occurs on seven of the sherds and consists of diagonal incised lines, multiple vertical incised lines (4), horizontal engraving on a bowl rim (1) and punctuates (2) (Perttula 1998). Perttula suggests that the site, based on the ceramic assemblage, may represent a single component Caddoan site dating possibly as early as A.D. 1100. Other 
Table 1. General Statistics for Sites Evaluated.

\begin{tabular}{||l|l|c|c|c|l|l||}
\hline $\begin{array}{c}\text { Site } \\
\text { Number }\end{array}$ & $\begin{array}{c}\text { Size } \\
\text { (sq. m) }\end{array}$ & $\begin{array}{c}\text { Excavation } \\
\text { (sq. m) }\end{array}$ & $\begin{array}{c}\text { Volume } \\
\text { Excavated } \\
\text { (cu. m.) }\end{array}$ & $\begin{array}{c}\text { Dates } \\
\text { Tested }\end{array}$ & Drainage & $\begin{array}{c}\text { National } \\
\text { Register } \\
\text { Eligible }\end{array}$ \\
\hline \hline 34 MC254 & 8,376 & 8 & 5.3 & $\begin{array}{l}\text { Mar., May, } \\
1997\end{array}$ & Parker Creek & Yes \\
\hline 34 MC517 & 4,830 & 35 & 18.5 & June 2000 & $\begin{array}{l}\text { Tributary of } \\
\text { Goodwater } \\
\text { Creek }\end{array}$ & $\begin{array}{l}\text { Testing not } \\
\text { completed }\end{array}$ \\
\hline 34 MC606 & 5,225 & 22.5 & 16.4 & $\begin{array}{l}\text { 4 June 1999, } \\
\text { Oct. 1999 }\end{array}$ & Parker Creek & Yes \\
\hline 34 MC737 & 2,700 & 15 & 7.3 & $\begin{array}{l}\text { Nov. 1996, } \\
\text { Jan. 1997 }\end{array}$ & Surratt Creek & No \\
\hline 34 MC760 & 972 & 26 & 15.8 & $\begin{array}{l}\text { May, June } \\
1999\end{array}$ & Parker Creek & Yes \\
\hline 34 MC762 & 2,800 & 14 & 8.2 & $\begin{array}{l}\text { Nov., Dec. } \\
1999\end{array}$ & Parker Creek & $\begin{array}{l}\text { Testing not } \\
\text { completed }\end{array}$ \\
\hline 34 MC769 & 2,736 & 10 & 5 & $\begin{array}{l}\text { Nov. 1997, } \\
\text { Oct. 1998 }\end{array}$ & Parker Creek & No \\
\hline 34 MC770 & 4,278 & 10 & 7.1 & $\begin{array}{l}\text { July, Aug., } \\
\text { Nov. 1997 }\end{array}$ & Parker Creek & Yes \\
\hline 34 MC789 & 3,060 & 12 & 5.8 & $\begin{array}{l}\text { Oct., Nov. } \\
1998\end{array}$ & $\begin{array}{l}\text { Tributary, } \\
\text { Coodwater } \\
\text { Creek }\end{array}$ & Yes \\
\hline
\end{tabular}

diagnostics include one arrowpoint and several Gary dartpoints. Some of the general site statistics are presented in Table 1.

\section{$34 M C 254$}

This site was originally reported in 1980 by the Museum of the Red River. It is a large site on an alluvial terrace adjacent to Parker Creek. It had previously been subjected to intense vandalism and had also been farmed and damaged by earlyday timber harvesting activities. Ceramics suggest a Fourche Maline component, in addition to a Caddoan component. Features identified include: a small oval pit filled with charcoal and sooty soil, a grinding slab standing on edge (although no associated pit was identified), and a small circular stain containing bone and fire-cracked rock. 
The remainder of this paper will provide some description of the work completed at the seven additional sites where evaluation testing has been undertaken since the previous update. Excavation methods include both troweling and shovel shaving. All soil was screened through $1 / 4-$ inch hardware cloth, except for the soil samples taken for flotation, OCR dates, grain size analysis, and phytolith studies. The organization in the following discussion is chronological, based on the dates that the sites were tested. Following this testing summary, a few comments regarding future investigations are made.

\section{$34 M C 770$}

This site is situated on an alluvial terrace remnant on the west side of Parker Creek. It is bordered on the east, north and west by remnant stream channels and on the south by a small side tributary of Parker Creek. The excavation of five $1 \times 2$-meter units revealed cultural deposits ranging to $60-80 \mathrm{~cm}$ below the present ground surface. All of the excavation units were situated on the southern third of the landform. Two were located on a low knoll and the remaining three were located in a midden adjacent to the south edge of the terrace.

Artifacts recovered include abundant charred nut hull fragments (mostly hickory nut), fire-cracked rock, lithic debris, arrowpoints and ceramics. Some poorly preserved bone fragments were also recovered. Soils consist of a homogeneous, very dark sandy loam. Based on the ceramics recovered from the initial site documentation, Perttula (1997:Table 8) suggests that the site contains a possible Early Caddoan and Late Caddoan Component.

Seven features were identified. These include: (1) a homogenous brown soil stain partially exposed in unit N62$63 / \mathrm{W} 23-25$ at $32 \mathrm{~cm}$ below surface (cmbs). A pitted stone, chert pebble and small bone fragment were collected from the top of the feature; (2) a cluster of three cobbles, possibly hammerstones at a depth of $30-40 \mathrm{cmbs}$ in unit N57-58/W18-20; (3) a soil stain exposed in profile in unit N62-63/W23-24 extending from $36 \mathrm{cmbs}$ to $60 \mathrm{cmbs}$; (4) a trash filled pit exposed in unit N38-39/W29-31; (5) a loose cluster of bone fragments in unit N30-31/W29-31 at $60 \mathrm{cmbs}$; and $(6,7)$ soil stains located in unit N30-31/W29-31.

Feature 4, the trash-filled pit exposed in the eastern end of unit N38-39/W29-31, warrants additional discussion. Approximately $20 \%$ of the feature was excavated. The fill was removed in $10 \mathrm{~cm}$ levels, and larger artifacts (bone fragments, sherds, etc.) were point plotted. Flotation samples and OCR samples were collected. Several sherds of Nash Neck-Banded and Simms Engraved (Suhm and Jelks 1962:111, 141) were recovered as were other incised, fingernail punctuated, and red-slipped sherds. This feature is likely associated with the Late Caddoan component on the site.

In January 1999, Kent Schneider, Forest Service Region 8 Regional Archeologist, visited the site and conducted a GPR survey across part of the southern portion of the terrace. Several anomalies were 
identified; however, at this time they have not been ground truthed.

\section{$34 M C 769$}

This site is also situated on an alluvial terrace remnant on the west side of Parker Creek, several hundred meters downstream from $34 \mathrm{MC} 770$, but is directly across the creek from sites $34 \mathrm{MC} 760$ and 34MC762. This terrace remnant contains three small knolls, and during the original documentation, the overall artifact density appeared to be low. Based on sherds recovered from the initial documentation, Perttula (1997:Table 8) suggests that this site contains a Caddoan component.

Five 1x2-meter excavation units were opened on the site. Four units were on the western end of the terrace, adjacent to the creek channel where shovel testing had suggested that the artifact density was highest. A thin midden was identified on the southwestern part of the terrace. No features were found. One unit on the northwestern corner of the site revealed cultural materials to a depth of $80 \mathrm{cmbs}$. Soils in this area consisted of a light brown clayey sand.

Cultural materials recovered included lithic debris, a few sherds, an arrowpoint and Gary dart points.

\section{$34 M C 789$}

This site is situated on several low knolls on the eastern floodplain of an unnamed tributary to Goodwater Creek. The knolls consist of gravelly sands, while the lower areas between the knolls consist of dense sandy clays. A GLO road crossed this terrace and cuts into the site deposits. After the turn of the century, this terrace was farmed.

Based on the artifacts recovered from the initial shovel testing of the site, an Archaic component was expected when testing began. Six 1x2-meter excavation units were opened. Five units were placed on the sandy knolls and one was in a low area between and north of the knolls. Artifact density on the knolls was low to moderate; no artifacts were recovered from the unit north of the knolls. No features were identified. With the exception of thin brown undecorated sherds and a few stemmed dart points, few diagnostics were recovered.

\section{$34 M C 760$}

This site is situated on a restricted alluvial terrace remnant north of, but immediately adjacent to, Parker Creek. Initial documentation indicated two primary areas of artifact density - adjacent to the south terrace edge along the creek and across a low knoll at the north edge of the site. Perttula (1997:Table 8) suggests Middle and Late Caddoan components based on the shovel test data. During a site visit in September 1998, vandalism was found to have recently occurred.

The Ouachita National Forest offered to host the 1999 Oklahoma Anthropological Society (OAS) field school, and because of the recent vandalism, it was decided that this would be a good site to test with OAS assistance (Ouachita National Forest 1999). 
A total of $131 \times 2$-meter excavation units were placed in three primary areas within the site. Five units were placed in the midden along the south edge of the terrace, one unit was placed in the central part of the terrace, and seven units were placed on the low knoll at the north end.

At the southern end of the site, where damage from the vandalism had been greatest, the excavation revealed midden and cultural materials to depths of 80 cmbs. Stemmed dart points, Gary dart points, and an abundance of ceramics were recovered from these units. Ceramics include a sherd or two of Nash NeckBanded, and abundant grog, bone and shell tempered sherds. Other artifacts included lithic debris, charred nut hulls, burned clay, charcoal, fire-cracked rock, and bone fragments. Three features were identified in this area. A circular stain in unit N20-22/E63-64 was first identified at $50 \mathrm{cmbs}$ with its bottom at $78 \mathrm{cmbs}$. The fill contained carbonized plant material. Soil stains, also identified as features, were located in units N12-14/E52-53 and N12-14/E50-51.

In the central portion of the site, one unit revealed cultural materials to a depth of 50 cmbs. Artifacts were similar to those found in the midden at the south end of the terrace; these included lithic debris, bone, ceramics, fire-cracked rock and charred nut hulls. An irregular shaped stain recorded as Feature 3 was partially exposed in the unit at a depth of $40 \mathrm{cmbs}$. Soils in this feature were ashy and contained charcoal flecks and bone.

On the northern end of the site, seven 1.2-meter units were placed on and around the edges of the low knoll. Based on initial documentation, it was suspected that a Caddoan structure might be located here. Evidence of old vandalism, as well as a recent pothole, was found in the center of the knoll. Overall, artifacts were considerably fewer than on the southern end of the terrace. Two adjacent $1 \times 2$ meter units (N40-42/E52-53, N40-42/E53$54)$ on the southwestern edge of the knoll were excavated to depths of $45 \mathrm{cmbs}$. A possible living zone was identified at depths ranging from about $40-45 \mathrm{cmbs}$. One vertical charred post remnant was also recovered. Additional charcoal fragments, possible remnants of another post, were located about two meters north (in the southern edge of unit N44-46/E5455). No further evidence of a living surface was identified in the other four units. Two features were documented in N42-44/E56-57. Feature 6 was identified as a dark stain at $60 \mathrm{cmbs}$, although artifacts point plotted in the $50-60 \mathrm{~cm}$ level may be associated. Bottom depth was at $71 \mathrm{cmbs}$. One Nash Neck-Banded sherd was recovered from this feature. Feature 7, another dark soil stain, was only partially exposed in the floor at $60 \mathrm{cmbs}$ and extended into the west wall of the unit.

The ceramics from these units at $34 \mathrm{MC} 760$ have been partially inventoried. Of those 647 sherds, decorated sherds comprise $22.9 \%$ of the sample. Decorative techniques include incised lines $(8.5 \%)$, engraved lines $(4.0 \%)$, applique $(2.1 \%)$, punctate $(1.7 \%)$, fingernail punctate (1.1\%), other $(5.5 \%)$. Tempering materials include grog $(57.8 \%)$, shell $(20.1 \%)$, grit 
$(12.2 \%)$, bone $(5.9 \%)$, clay $(2.2 \%)$, and sand $(1.1 \%)$.

\section{$34 M C 606$}

This site is situated on an east-bank alluvial terrace above Parker Creek. A portion of the terrace is bordered by an old, mostly-filled slough. Forest Service employees originally documented this site in 1991 following a timber harvest. One knoll, containing cultural materials to 75 $\mathrm{cm}$ depths, had been identified on the site. Due to its proximity to $34 \mathrm{MC} 760$, and the recent occurrence of vandalism, it was selected as a second site to be tested with the 1999 Oklahoma Anthropological Society field school.

Ceramics collected during the earlier documentation suggested that a possible Woodland component, as well as Early and Late Caddoan components might be present (Perttula 1997:Table 8). It was believed that the testing would recover a better sample of ceramics, and would also allow a determination of whether the knoll was a natural or a cultural feature.

During and following field school, eleven 1x2-meter excavation units were placed on the site. Eight units were placed on the terrace west of the knoll, one north of the knoll, and three on the knoll and one east of the knoll. Of those eight located on the terrace east of the knoll, five were on the terrace edge. Cultural deposits ranged from about $40-90 \mathrm{cmbs}$. The remaining three units were on terrace locations nearer the knoll. Cultural deposits ranged in depth from $20-50$ cmbs in two of the units. The unit nearest the western foot of the knoll contained the most midden-like soil observed on the site, and deposits extended to $80 \mathrm{cmbs}$. This unit also contained more bone fragments than any of the others. Features identified in these areas consisted of soil stains and one shallow basin-shaped pit.

The unit north of the knoll, excavated to a depth of $60 \mathrm{cmbs}$, contained a light density of cultural materials. The unit east of the knoll was excavated to a depth of $20 \mathrm{cmbs}$ and was basically sterile.

The knoll is within the western edge of a dense pine plantation/thicket and is situated on the eastern edge of the site. The knoll extends about $80-90 \mathrm{~cm}$ above the surrounding terrace surface. Three 1 $\times 2$-meter units were placed on the knoll. The first (N75-77/E74-75) was located on the northern slope and was excavated to a depth of 130 cmbs. Soils were a light brown sandy loam overlying white sand. Stratigraphy was defined more by texture than by color change. Artifact content was light, but continuous to a depth of about one meter. Two additional $1 \times 2$-meter units were placed near the center of the knoll. In unit N69-71/E73-74, ashy soil and charred beam fragments were exposed from 40 $50 \mathrm{cmbs}$. These timbers were discontinuous, but extended diagonally across the unit from southeast to northwest. A solid section of charred log was oriented diagonally across the northeastern corner of the unit at a depth of $64-69 \mathrm{cmbs}$. The sandy soil around and east of the charred timbers was obviously burned. The third and final unit on the knoll (N70-72/E7576) was excavated to a depth of $95 \mathrm{cmbs}$. Beginning in the $50-60 \mathrm{~cm}$ level, soil 
stains and charcoal fragment began to be exposed. The top of a charred post (?) was exposed in the western wall of the unit at 71 cmbs. This charred log fragment is $21 \mathrm{~cm}$ in diameter and the bottom depth was at $94 \mathrm{cmbs}$. A large irregular burned patch of sandy soil was located in the floor of the unit at $85-90 \mathrm{cmbs}$, with a bottom depth at $101 \mathrm{cmbs}$. Numerous flotation samples were removed in $5 \mathrm{~cm}$ levels and in $50 \mathrm{~cm}$ square blocks in the lower levels of the unit.

Based on these excavations, we can readily say that the knoll is not natural, but was a low mound built over a burned structure.

\section{$34 M C 762$}

This is one of the sites on which testing has been done more recently, although this work has not yet been completed. This site is also located on an alluvial terrace remnant on the northern side of Parker Creek. It is bordered on both the east and west ends by the creek channel. The testing on this site was accomplished, in part, through the use of several Native American students, BIA and Forest Service employees enrolled in a Forest Service Heritage Resources Technician training session.

Seven 1x2-meter units were excavated. The excavation units were placed in areas defined by shovel testing as localities with higher artifact densities where features might be present.

Three units (N50-52/E71-72, N5254/E70-71, and N54-56/E71-71) exposed

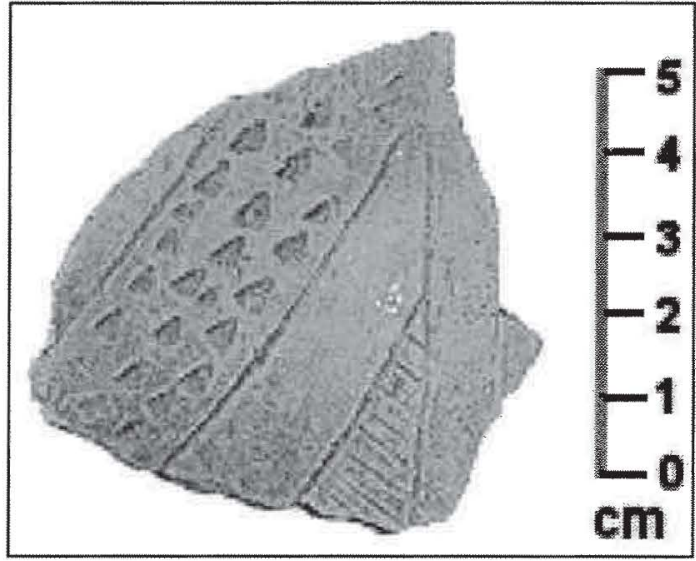

Figure 1. Crockett Curvilinear sherd from unit N52-54/E70-71 (20-30 cmbs).

a midden to $60-70 \mathrm{cmbs}$. This midden contains an abundance of both burned and unburned bone fragments, nut hulls, and ceramics (Figure 1). A few soil stains were documented as features, although continued investigation suggested that some were a result of rodent disturbance.

\section{$34 M C 517$}

This is the most recently investigated site, and testing here also is not yet completed. The Ouachita National Forest hosted the Oklahoma Anthropological Society field school at this site in June 2000 (Ouachita National Forest 2000)

This site, originally documented in 1990 , consists of three knolls on the western floodplain of an unnamed tributary to Goodwater Creek. Knoll A is the northernmost knoll and is adjacent to and west of an old, mostly-filled, creek channel. The current creek borders the site immediately north of this knoll. Knolls B 
and $\mathrm{C}$ are located about 60 - 80 meters south-southeast of Knoll A. The current creek channel is about 75 meters east of these two southern knolls.

Three $1 \times 2$ meter excavation units were opened on Knoll A. Soils consist of homogeneous brown/dark brown silty loam. Artifact density was moderate and small gravels were abundant. A medium density scatter of burned rock fragments

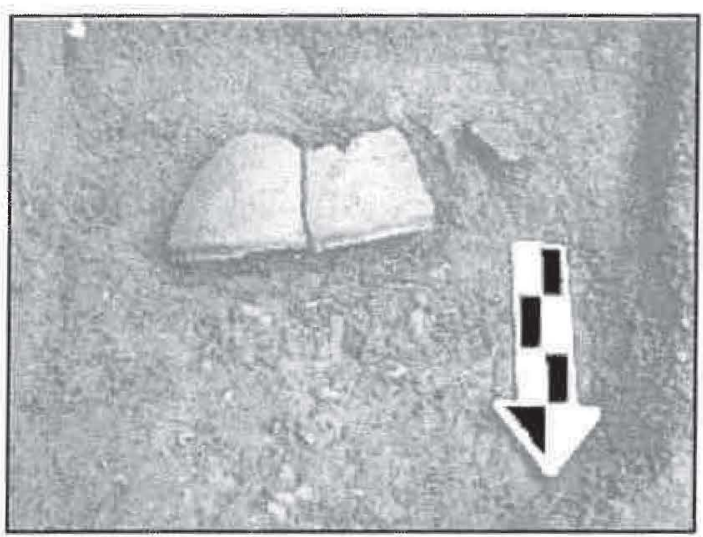

Figure 2. Feature 3, large sherds, at $46-49$ cmbs, N41-43/E65-66.

were identified in two of the lower levels in unit N108-110/E35-36 (levels 50 - 60 and $60-70 \mathrm{cmbs}$ ). No features were identified in any of these three units. Ceramics include fingernail pinched and cane punctate sherds, as well as a few incised and engraved sherds. One Catahoula-like arrowpoint and one Dalton point stem were also recovered.

Knoll B consists of a low, oblong knoll with a higher "mound" on the southern end. The top of this higher "mound" is approximately $55 \mathrm{~cm}$ higher than the northern extension of the knoll and about $85 \mathrm{~cm}$ above the current terrace surface off the knolls. A current interpretation is that this higher "mound" was constructed on an existing "natural" knoll located on the floodplain.

Seven $1 \times 2$ meter units were placed on Knoll B. Two units were excavated to depths of $90 \mathrm{cmbs}$; one of these units was on top of the higher southern part of the knoll and one was immediately to the north. The remaining units were each placed on the lower northern extension of the knoll. One feature included a large sherd (Figures 2 and 3 ) at $46-49 \mathrm{cmbs}$ in unit N41-43/E65-66. This unit was located on the higher part of the "mound." This is a grog tempered rim sherd from a large jar

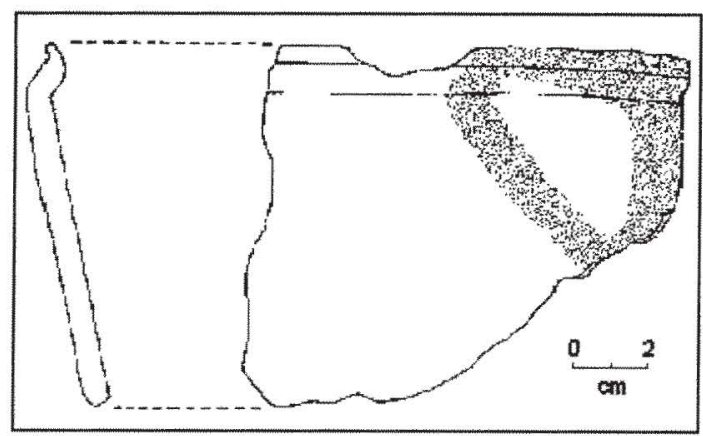

Figure 3. Drawing of a portion of the sherd from Feature 3, Unit N41-43/E65-66 and cross section. Stippled area is red slip/paint.

or bowl. Exterior color is brown $(7.5 \mathrm{YR} 4 / 6)$ with a large patch of dark red slip or paint $(2.5$ YR3/6). Several more features were identified on this knoll including clusters of burned sandstone; burned sandstone with associated burned and thermally fractured chert cobbles; and 


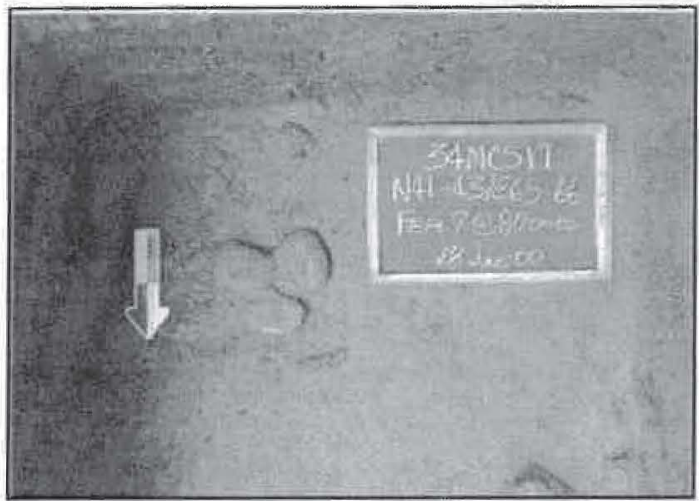

Figure 4. Feature 7, cluster of anvil stones, at $80 \mathrm{cmbs}, \mathrm{N41-43/E65-66.}$

a cluster of anvil stones (Figure 4). Ceramics were mostly plain brown sherds, although a few incised sherds were found. Small, stemmed dart points (Gary and small rectangular stemmed points), and small arrowpoints were also recovered.

Knoll $\mathrm{C}$ is immediately southeast of Knoll B. Six $1 \times 2$ meters units, two $0.5 \times 2$ meters units and one $0.5 \times 1$ meter unit were placed on this knoll. Artifact density was low to moderate. Several plainware sherds, small stemmed dart points (Gary and rectangular stemmed) and arrowpoints (bulbous stemmed - Bonham-like) were located. Overall, the depth of cultural deposits is slightly less than on the other two knolls. Unlike the other two knolls, however, this one is covered with a thin (15 - $20 \mathrm{~cm}$ thick) lens of a highly mottled gray silty loam. Underlying this gray soil is a homogeneous brown silty loam.

A series of small thin charcoal "tablets" (approximately $10 \mathrm{~cm}$ long $\mathrm{x} 4 \mathrm{~cm}$ wide $\mathrm{x}$ $1 \mathrm{~cm}$ thick) were located on the western edge of the knoll in the area of N2125/E74.5-76. A scatter of small charcoal chunks and flecks were found intermixed with the charcoal "tablets"; these materials occur at the base of the mottled gray soil. These charcoal "tablets" are lying flat or tilted slightly to the side. Although no posts were identified, these are tentatively identified as remnants from a burned structure.

Overall, the lithic debris recovered from this site is rather sparse. In looking at materials as they were recovered from the screens and in the lab as they were being processed, it appears that the occurrence of novaculite flakes is high; the remaining lithic materials appear to be coming from the local gravels. Bone fragments and charred nut hulls are almost nonexistent on this site, unlike on most sites described above.

\section{OBSERVATIONS}

A few observations may be made that apply to each of the sites investigated. All of the sites in this general region have been found to have disturbances that can be attributed to vandalism. In most cases, this disturbance is old and is evident by shallow depressions with associated low backdirt piles. In only few instances has recent (new) vandalism been discovered, and usually this has followed the Forest Service investigations. 
Soils on the sites are generally very sandy with low clay content. Small gravel pebbles are almost non-existent to moderately abundant. Of the sites tested, all are within the Red River drainage basin except 34MC789 and 34MC517; these two sites are in the Little River drainage basin. Gravels are much more abundant on the knolls on these two sites than those in the Red River drainage.

Rodent disturbance is generally low to moderate. However, in the lower deposits at 34MC254 disturbance was high. In one unit at 34MC762, the critter tunneled through the excavation unit as the excavation was underway.

Lithic debris occurs in low to moderate densities and consist mostly of local materials. These local materials consist of various chert (gray, black, brown, mottled, yellow, red), some quartzite, "Potter chert" and an occasional silicified wood flake. Novaculite occurs on most sites, but comprises a low percentage of the overall lithic assemblage. Several sites also have produced quartz crystal flakes, and two (34MC254 and 34MC606) have produced quartz crystal arrowpoints. The majority of the lithics are derived from the local gravel cobbles, likely from the Red River as well as the Little and Kiamichi River drainages.

Relying heavily on shovel testing, even on a finely spaced grid, for site interpretation is risky. Two of these sites that have been tested in this exchange project (34MC737, 34MC789) were believed, based on the shovel test data, to be primarily Archaic sites. Excavation of the test units has revealed otherwise. By the same token, it is risky to make wide scale interpretations based on widely spaced excavation units on a large site. Based on site size (square meters) and areal extent of the excavations, the percentage of site area investigated during this project ranges from a low of $0.01 \%$ on site $34 \mathrm{MC} 254$ to a high of $2.7 \%$ on site $34 \mathrm{MC} 760$.

\section{UPCOMING WORK}

Several sites remain within this McCurtain County project area that need to be tested for their eligibility for the NRHP. The following discussion identifies a few of these.

\section{Sites with predominately Caddoan com- ponents}

Some of those sites that still need to be further evaluated include five additional sites with Caddoan components documented during the survey phase of this project and two sites previously documented.

One of these is within the Parker Creek drainage (34MC776). This site, covering about 2100 square meters, was found to contain deposits ranging from about $40 \mathrm{~cm}$ to $60 \mathrm{~cm}$ depth. A few charred nut hulls, bone fragments, and charcoal fragments were recovered from the shovel tests, in 
addition to the usual ceramics, lithic debris and burned rock.

Three sites are within the Norwood Creek drainage, though not directly on Norwood Creek. Sites 08-09-12-150(77) and 08-09-12-150(78) were documented during the survey phase of this land exchange project. These small lithic and ceramic sites are adjacent and may be related. Artifacts were recovered to depths of $40 \mathrm{~cm}$ in the sandy terrace deposits. Site $34 \mathrm{MC} 665$, previously documented by New South Associates (Guan et. al. 1996), is also in the Norwood Creek drainage. This site is documented as a small Caddoan hamlet with a rich midden covering an area of approximately 900 square meters. Ceramics include incised, zone punctate, and plain sherds.

Three sites are located in the Mud Creek drainage. One site (34MC256), previously recorded by the Museum of the Red River, is adjacent to a small stream channel and a slough [swamp] (Perino 1979; Bennett 1980). This site was identified as covering approximately 2250 square meters. The original investigation in 1979 recovered two bone-tempered sherds and several dart point fragments and pieces of lithic debris. A revisit to the site in 1997 recovered a few additional sherds and lithic debris. Two additional sites, both adjacent to the swamp on the east and south, were documented as part of the survey phase of this current land exchange project. Site $10 / 8 / 97-1$ is located at the eastern end of the swamp and consists of an oblong knoll. Shovel tests revealed primarily lithic debris and burned rock fragments. One shovel test contained burned clay and a sherd was recovered from one additional test. Site 10/8/97-2 is located along the southern side of the swamp. This site is situated on a series of knolls. Shovel tests reveal cultural deposits to $40-60 \mathrm{~cm}$ below ground surface on the knolls, but at a much shallower depth on the flat areas between the knolls. Several small Gary and Gary-like dart points were recovered, as was one arrowpoint. Few sherds were recovered.

\section{Sites with predominately Choctaw com- ponents}

Several Choctaw farmsteads dating from as early as the $1840-50$ s into the early 20 th century need additional evaluation. These include previously documented sites as well as sites identified through the Choctaw allotment records search.

Although one of these sites (34MC733), in the Surratt Creek drainage, was damaged by timber harvest activity $15+$ years ago, and again very recently, the main central portion of the site was relatively undisturbed. However, additional recent disturbances consist of vandalism within the core site area. Artifacts recovered from the original shovel test documentation, as well as materials recovered from vandal's backdirt piles, suggest an age range from the early part of the mid-19th century to as recently as the $1930 \mathrm{~s}$ or $1940 \mathrm{~s}$. This site is also reported to include a small family cemetery (Etchieson n.d.).

A second site, 34MC576, is located within the Mud Creek drainage (Haikey 1994). This site is multi-component. The prehistoric component consists of a lithic 
scatter with depths ranging from $40-100$ $\mathrm{cm}$. Diagnostics recovered included three projectile points (including Gary, Ellis and Yarborough types) and one small fragment of shell-tempered ceramics. The historic component consists of an early Choctaw homestead, reported as the Herron Homestead. One feature, a large cellar depression, was identified.
Several additional historic sites, mostly farmsteads, were documented during the survey phase of this project and during the Choctaw allotment records examination. Several of these Choctaw farmsteads also contain small associated family cemeteries. At this time, however, which of these farmsteads may need further evaluation is undetermined.

\section{ACKNOWLEDGMENTS}

All of those volunteers who have donated significant amounts of time toward the accomplishment of this testing deserve a special thanks. Among those who have put in large amounts of time, in the field and in the lab, include: Mark Walters, George Gatliff, Harry Hammond, Mildred Grissom, Charles Surber, and Hardee and Cheryl Jerrels. Last, but certainly not least, all of the members of the Oklahoma Anthropological Society are to be commended for their bravery during thunderstorms, drenching rain, humidity and mosquitoes to assist with the field and laboratory work during the past two years. Volunteers who have participated on this project have been from Oklahoma,
Arkansas, Texas, Mississippi, Missouri, Illinois and England. The HRT students who participated in site $34 \mathrm{Mc} 762$ testing represented the Caddo Tribe, Choctaw Nation, Creek Nation, Cherokee Nation, BIA, and Forest Service. Thanks for all the wonderful work.

In addition, I should thank the management of the Ouachita National Forest and the Weyerhaeuser Company for their continuing encouragement and support in the accomplishment of this project. Also, thanks to Roger Coleman for the drawing of the sherd from $34 \mathrm{MC} 517$ and for reviewing an earlier draft of this report.

\section{REFERENCES CITED}

Bennett, W. J., Jr.

1980 Archaeological and Cultural

Resource Survey of Twenty Three

Compartments in the Tiak Ranger

District, McCurtain County,

Oklahoma. Report submitted to the
Ouachita National Forest by the

Museum of the Red River, contract no. 53-43-ZP-8-00143.

Etchieson, Meeks

n.d. An Archeological Survey of Lands 
Included in the Ouachita National Forest/Weyerhaeuser Land Exchange Project: Arkansas and Oklahoma. Report in preparation.

$1997 \mathrm{O}$ u a chit a $\mathrm{Nat}$ ion a 1 Forest/Weyerhaeuser Company Land Exchange. Caddoan Archeology $8(2): 17-27$.

Guan, Gary X, Leslie E. Raymer, Christine Van Voorhies, Mary Beth Reed, and Craig Hanson

1996 An Archaeological Survey of 4,444 Acres of the Oden, Mena, and Poteau Districts in Arkansas and the Tiak and Kiamichi Districts in Oklahoma of the Ouachita National Forest. New South Associates Technical Report 259. Stone Mountain, Georgia.

Haikey, Larry D.

1994 Report for Inventory of 480 Acres for Fiscal Year 1995 Timber Sale Activities in Compartments 5 and 30 , Tiak Ranger District, Ouachita, National Forest, McCurtain County, Oklahoma. Report 94.09 .26 on file in the Supervisor's Office, Ouachita National Forest, Hot Springs, Arkansas.

Ouachita National Forest 1996 Programmatic Agreement Regarding Cultural Property Protection and Responsibilities for the Weyerhaeuser/Ouachita National Forest Land Exchange Among The Advisory Council on Historic Preservation, Weyerhaeuser Company, The Oklahoma State Historic Preservation Officer, The Oklahoma Archeological
Survey, The Arkansas State Historic Preservation Officer, the Caddo Tribe of Oklahoma, the Choctaw Nation, and the Ouachita National Forest. Signed by the Advisory Council, 18 September 1996.

1999 Participating Agreement Between Ouachita National Forest and the Oklahoma Anthropological Society and Archeological and Environmental Consultants. Tiak LX Project.

2000 Participating Agreement Between Ouachita National Forest and the Oklahoma Anthropological Society. Tiak LX Project.

Perino, Greg

1979 34MC256: The Oklahoma Archaeological Survey Data Record. 4 September 1979.

Perttula, Timothy K.

1997 An Analysis of Aboriginal Ceramics From Sites in the Tiak Land Exchange, McCurtain County, Oklahoma. Archeological and Environmental Consultants. Austin, Texas.

1998 Preliminary Observations on the Caddoan Ceramics from $34 \mathrm{Mc} 737$. Archeological and Environmental Consultants. Austin, Texas.

Suhm, Dee Ann and Edward B. Jelks

1962 Handbook of Texas Archeology: Type Descriptions. The Texas Archeological Society, Special Publication Number One and The Texas Memorial Museum, Bulletin Number Four. Austin, Texas. 